\title{
O heterônimo ortônimo e o Álvaro de Campos: do tempo mítico ao tempo das efêmeras sensações
}

\author{
André Boniatti ${ }^{\top}$
}

Ana Maria Martins Alves Vasconcelos ${ }^{2}$

\begin{abstract}
RESUMO: Sabe-se que os mistérios que se ocultam perante a imarcescível imaginação de Fernando Pessoa, poeta português moderno, são ainda motivo de estudos profundos, tanto mais mediante a popularidade que o poeta alcançou com o reconhecimento após sua morte, dele merecido, e a passagem dos anos. O presente artigo, perante as diversas inquietações que sua obra suscita, investiga um dos vieses da relação que pode ser estabelecida entre os heterônimos pessoanos Álvaro de Campos e Pessoa ele mesmo, ortônimo, almejando compreender tanto as raízes que lhe conturbam a sua efetivação material identitária, quanto a tentativa que empreende em conceber-se alguém. Assim, o próprio Pessoa ele mesmo, tratamo-lo aqui como heterônimo, visto entendermos a identidade pessoana perdida entre suas personas imaginadas/desenhadas por si. No decorrer da leitura, essa proposição mostra-se clara, em face do entendimento de o poeta heteronímico Campos apresentar-se o "eu" mais próprio de Fernando, trazendo à tona ao menos uma possibilidade de agrupamento de sua multiplicidade.
\end{abstract}

PALAVRAS-CHAVE: Fernando Pessoa; Heteronímia; Literatura Portuguesa.

\section{The orthonymous heteronym and Álvaro de Campos: from the mythical time to the ephemeral sensations one}

\begin{abstract}
It's well known that the hidden mysteries behind the modern Portuguese poet Fernando Pessoa's great creation are still motive to profound studies, so much more towards the popularity the poet reached with his after dead recognition, forever deserved, in the years' passage. The present research, before the several unrests his poems bring, investigate something about the relation we can establish between the Pessoa's heteronyms Álvaro de Campos and Pessoa himself, orthonymous, searching to find so much the roots that perturb the material effectuation of his identity, as the attempt he launches toward the affirmation of his I. During the lecture, this proposition will be clear, front the understanding that Campos seems to be Fernando's most proper "I", bringing to surface at least a possibility of his multiplicity's grouping.
\end{abstract}

KEY-WORDS: Fernando Pessoa; Heteronymy; Portuguese Literature.

Os heterônimos pessoanos desenharam um dos maiores mistérios da imaginação

\footnotetext{
${ }_{1}^{1}$ Professor da Universidade Estadual do Oeste do Paraná. Doutorando em Letras pela Universidade Estadual do Oeste do Paraná.

2 Professora de Inglês e Francês da Universidade Estadual do Oeste do Paraná. Doutoranda em Letras pela Universidade Estadual do Oeste do Paraná.
} 
literária da modernidade. Cada um deles não era uma simples invenção fictícia de personagens romanceados no mundo da literatura. Cada um deles tinha, na verdade, uma vida aparte na realidade intelectual do mundo efetivo, uma ideologia, um ideal e um modo diversos no escrever. Ousar-se-ia dizer que uma existência física crível, dada através das letras. Ao lê-los, a poética de cada qual tem sua peculiaridade e sua verve íntima. Cada um deles traz sua história, uma personalidade avulsa palpável e até mesmo um mapa astral, afundado que se via Pessoa em estudos místicos.

Mostra dessa imersão mística está no heterônimo dito ortônimo, o Pessoa ele mesmo, que afogara para dentro de si e, submerso, perdera-se da realidade física fazendo-se Dédalo (ele) dele mesmo. Estava imerso nas névoas do ser. E as névoas, imersas no corpo, adensando sua alma, faziam do Ser um emaranhado turvo de sombras e promessas. Promessas essas que nunca viriam a se cumprir efetivamente, mas que se projetariam como luz difusa em catedrais silenciosas, em templos monásticos de saltérios nevoentos. Quando Pessoa canta o mar português, no livro Mensagem, ele evoca os mitos da esperança e debate acerca do declínio e da depressão, interpondo-lhes a fé patriótica, entorno de uma nova Nação, nação que voltasse ao tempo épico dos feitos grandiosos e, assim, trouxesse heróis para o Império, nunca deveras conquistado por Portugal, mas insistentemente sonhado de entre a cerração. Como o poeta justificasse o devaneio que o movia à profecia do Império, a partir da figura apaixonada do D. Sebastião mítico: "Minha loucura, outros que me a tomem / Com o que nella ia. / Sem a loucura que é o homem / Mais que a besta sadia, / Cadaver addiado que procria?” (PESSOA, 1997, p. 76).

Só se se insurgisse da loucura heroica, embora desastrosa, de um rei ansiado pela emancipação de seu reinado, sob a paixão trágica dos mitos, — como cada cidadão agora se fizesse discípulo sonâmbulo do ímpeto louco de D. Sebastião, de forma a erguer a espada pelo sentimento nacionalista —, só assim se faria possível a volta de Portugal ao tempo das naus e das conquistas. Pois então D. Sebastião voltava, não nas cruzadas do mundo, mas na alma de um povo que agora não mais o esperasse, mas que enfim o revelasse, mostrando-o a terras estrangeiras e a nações com o signo do império, o Quinto Império de Portugal ${ }^{4}$. Ao mito sebastianista, faz-se-lhe então o retorno, mas na alma do poeta, se avivando nele: “Ah, quanto mais ao povo a alma falta, / Mais a minha alma atlantica se exalta / E entorna, / E em mim,

\footnotetext{
${ }^{3}$ A grafia das palavras seguem a publicação aqui utilizada, não sendo corrigido o português arcaico empregado por Fernando Pessoa no livro "Mensagem".

4 O “Quinto Império” pertence à propagação de uma crença messiânica pelo Pe António Vieira no séc. XVII: “Os quatro primeiros impérios eram, segundo o padre António Vieira, pela ordem: os Assírios, os Persas, os Gregos e os Romanos. O quinto seria o Império Português" (http://pt.wikipedia.org/wiki/Quinto Império).
} 
num mar que não tem tempo ou spaço, / Vejo entre a cerração teu vulto baço/ Que torna." (PESSOA, 1997, p. 82).

Desses versos transborda a pequenez intrínseca da alma das massas, contrária à de Pessoa, que trazia o tamanho e a vastidão atlântica de mares, mares tais que, emergindo dos passados mitos, a partir dele, outra vez se navegavam. Sua alma "entorna" tal qual derramasse em veios oceânicos, que vertessem de um pathos de fé e de esperança melancólicas, mas que exuberantemente grandes se entornassem em favor do escudo de sua Pátria. E, assim, a boçalidade da alma filisteia de seu povo: estúpida ou descrente, asfaltizada e maciça, é contradita com a sua, que renasce do mito e que planta as passadas naus a um tempo novo, o novo tempo épico da espada e do brasão. Dessa leva, o Pessoa ele mesmo vê-se um ser diverso das próprias massas de que é partícipe, pois que essas buscavam no ter a felicidade e o conforto, se fazendo, pelo ter, seguras ou falsamente ricas em sua mesquinhez, assim resignadas. Mas ele não se contentaria com o ordinário espiritual de seu povo.

“Ter é tardar” (PESSOA, 1997, p. 71), dizia ele. Ora, o ter amua o sonho da conquista. E, se não há o sonho, não há de haver espadas ou vitórias. O sonho de quem possua o objeto de desejo concretizou-se, pois então não é mais nada. A esses, vale-lhes o sossego mesquinho do lar.

\footnotetext{
Triste de quem vive em casa,

Contente com o seu lar,

Sem que um sonho, no erguer de asa,

Faça até mais rubra a brasa

Da lareira a abandoner!
}

Triste de quem é feliz!

Vive porque a vida dura.

Nada na alma the diz

Mais que a lição da raiz -

Ter por vida a sepultura.

(PESSOA, 1997, p. 84).

É preciso, portanto, navegar. Mas o Pessoa ele mesmo navegava as nebulosas, como dizia mais acima nos versos citados de "A última nau", quando contemplava o vulto baço do rei voltando de entre a cerração, retornando nele, "num mar que não tem tempo ou spaço" (PESSOA, 1997, p. 82): O veio nebuloso que o leva recebe a profecia do retorno sebastianista 
num tempo sempre presente, porque é o tempo do ser; quando a ideia, o sumo do mito, apossa sua alma e nele próprio consuma-se então o espaço mítico dos tempos de glória, em sua essência. Mas esse ser presente, do eterno presente (do tempo mítico), esse ser tenciona-o a amoldar o invisível, formar-lhe o informe, perder-lhe o achado: "Deus guarda o corpo e a fórma do futuro, / Mas Sua luz projecta-o, sonho escuro / E breve” (PESSOA, 1997, p. 82).

A luz de Deus, de forma que se projete no poeta, só poderá projetar-lhe mesmo sombras, através dele, sombras de uma realidade sonhada que ainda não pudera tomar corpo aparente no mundo sensível, pertencendo, assim, tão-só ao devaneio e ao delírio. Pertencente, assim, à loucura do ser (numa remissão ao seu sebastianismo). E como essa sombra, confrontada com o Ser Absoluto e projetada ao rés do sonho, do sonho escuro e breve dos relampejos da profecia, como ela lhe desenha a névoa do inabitado e obumbra o seu entendimento, assim o Pessoa ele mesmo contempla o sono do indecifrável de si e da realidade que o cerca.

Dissera Heráclito um dia: "Se não esperar o inesperado não se descobrirá, sendo indescobrível e inacessível" (PRÉ-SOCRÁTICOS, 2005, p.89). Ora, se não se é capaz de esperar o devir virtual de um fenômeno, ou o próprio absurdo deste, quando este devir puder vir a ser realmente, restará o espasmo e o assombro de quem se depare com ele, - então ele não será acessível ao conhecimento, porque se fará fantasma da consciência, mistério do irracional. Não se descobrirá: atirará contra a razão e esta sucumbirá à sua presença. Mas se "o corpo e a fórma do futuro" puderem ser velados no presente, serão conluiados em sua própria essência e o mistério desvendar-se-á tão logo aparente o problema. Entretanto, sob uma interpretação mais próxima do Pessoa da "Mensagem", o problema do futuro, do corpo velado de um presente potencial a vir fazer-se, este só poderá sobremaneira aparentar se for assim esperado: tão-só esperando o inesperado se é possível fazer-lhe deveras corpo no presente vindouro, potencializando um devir sonhado para que, enfim, se amostre a forma almejada. E só assim, pois, se poderá conquistá-lo verdadeiramente. De outra forma: como nos armaríamos contra o inesperado ou mesmo a favor dele? Como o descobriríamos antes que ele nos destruísse? Como nos moveríamos em direção a ele?

O Pessoa ele mesmo não só esperara o inesperado, mas convivera com ele. E como este não se mostrasse a ele em corpo, porque o poeta sondava o ser, pois então ele também não poderia descobrir-se a ele próprio ou mesmo sondar suas partes, tão só se afogar no indescobrível de si mesmo. Assim, se lhe destinara o mesmo redemoinho esfumaçado à alma que levara o seu amigo poeta Sá Carneiro à insuportabilidade do cotidiano: "Volteiam dentro 
de mim, / Em rodopio, em novelos, / Milagres, uivos, castelos, / Forcas de luz, pesadelos, / Altas torres de marfim" (CARNEIRO, 1976, p. 59).

E também o antológico:

Perdi-me dentro de mim

Porque eu era labirinto,

E hoje, quando me sinto,

É com saudades de mim.

(...)

Como se chora um amante,

Assim me choro a mim mesmo:

Eu fui amante inconstante

Que se traiu a si mesmo.

(...)

Não perdi a minha alma,

Fiquei com ela, perdida.

Assim eu choro, da vida,

A morte da minha alma.

(CARNEIRO, 1976, p. 48).

Assim era o poeta do "Cancioneiro". Sempre em desavença consigo. De alma perdida. Tateava a noturnidade de si para poder-se encontrar, mas quanto mais se aproximava daquilo que pensara ser, mais se tornava distante do que era: "No mal-estar em que vivo, / No mal pensar em que sinto, / Sou de mim mesmo cativo, / A mim mesmo me minto" (PESSOA, 1997, p. 174).

Assim como Sá Carneiro, o poeta vive o mal-estar da cotidianidade, mas não a cotidianidade monótona da civilidade, o poeta está afundado no mal-estar intelectual de sua alma atlântica, que é de si mesma cativa — desde que rodopiam nele, como às imagens de Sá Carneiro, várias possibilidades de si mesmo, vários eus que se existem dele, em "novelos", "uivos", "castelos", "pesadelos", e o ele dele, assim, definha na fumaça. Em face de que dele outros eus a ele moldem, então ele próprio deixa de existir. Porque, se a unidade, albergando o múltiplo, perde-se em favor de suas partes, a multiplicidade pensará o uno em vez do eu, e o uno far-se-á mistério então do múltiplo. É, portanto, compreensível que ele seja assim cativo de si mesmo, e é compreensível também que ele nele a um tempo só a si se encontre e não se 
tenha em si deveras, e não se possa ser enfim: "Nesta hora mais que em outra choro / O que perdi. / Em cinza e ouro o rememoro / E nunca o vi” (PESSOA, 1997, p.136).

Como ao labirinto de Sá Carneiro, que tinha a alma perdida sem que a houvesse perdido deveras, mas que sim a possuía (a ela) nele perdida, se perdendo de maneira ele dele próprio, mas em voga de si mesmo e não do outro; como ao labirinto inespacial dos rodopios desnorteados daquele poeta, dentro de si, também Pessoa tinha a alma perdida, em visão de que não pudera ater o próprio eu, nem conhecê-lo ou mesmo o pensar em sua memória, já que em cinza e ouro rememorava-o sem nunca o ter visto verdadeiramente. A dor da falta e da ausência do que houvera possuído e então perdido fá-lo memorar uma posse ao mesmo tempo luzidia e concreta, como o ouro nítido de ao sol, e fugidia e dispersa, como as cinzas no tempo. Mas tudo que de ao sol mostrou-se em ouro não se pode, pois, em cinzas desfazer-se. A não ser que fosse o lusco tão só o fosco de uma realidade assim sonhada. Então, o que se houve vislumbrado em cinza e ouro, de fato nunca se houve vislumbrado: - E nunca o vi, mas tão somente memorado envolto em ouro enquanto cinza e como cinza dispersando-se à luz do ouro, sendo assim nada mais que a possibilidade virtual de uma realidade presente, mas que nunca existira, que fora o sonho do que fora, a perfeita realidade de um ser efêmero perdido. Perdido não no tempo, mas no presente eterno de suas possibilidades, que alevantassem da vaguidão luzidias tal é o ouro e, num repente, esvaíssem-se a si próprias. De maneira que ao Pessoa ele mesmo restara-lhe apenas a angústia funda da impotência eterna da unidade perante o múltiplo, do ser em voga da esquizofrenia de um espírito diviso, partido, fragmentado. E essa angústia que lhe trazia a sua eterna dispersão, essa mesma angústia lhe traria ainda outra, maior: a de não poder deverasmente conceber nem sequer em que angústia havia imerso, a angústia de quem é que sofria — se não era a dele mesmo, quem era dentro dele que o fazia angustiado, — se não era ele mesmo; enfim, se ele não era ele, mas sim uma multidão que dele se existia. Porventura, nem confessar a própria angústia poderia, nem de maneira alguma a afirmar, de forma a ser possível que afirmasse assim um eu na confissão. Mas a confissão lhe era inútil: “Ah! A angústia, a raiva vil, o desespero / De não poder confessar / Num tom de grito, num último grito austero / Meu coração a sangrar!” (PESSOA, 1997, p. 137). E se lhe dera a noite: "Neste momento insone e triste / Em que não sei quem hei de ser, / Pesa-me o informe real que existe / Na noite antes de amanhecer" (PESSOA, 1997, p. 163). E junto da noite se lhe dera o sono: 


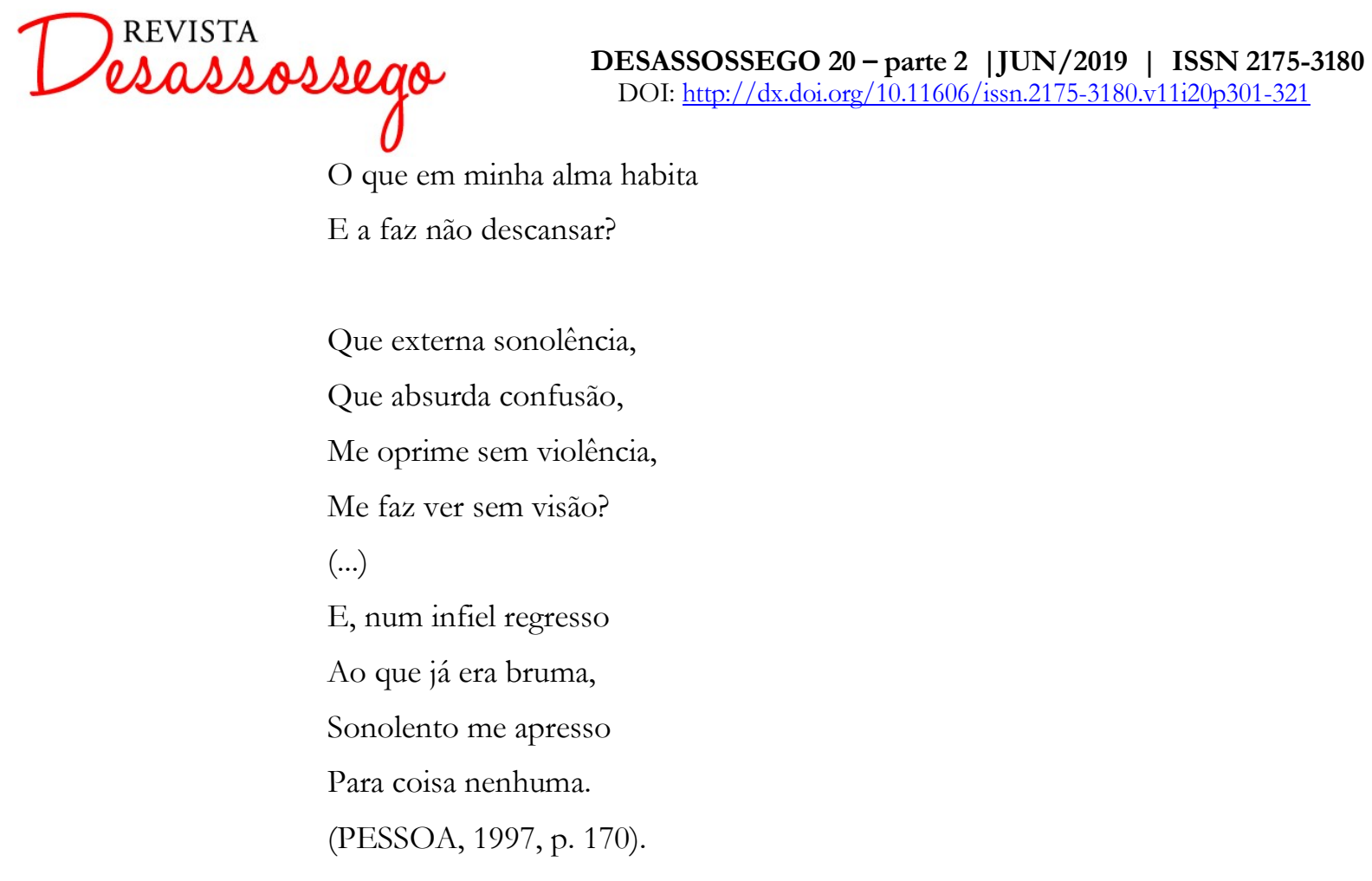

O "informe real" que se mostra a ele, "na noite antes de amanhecer": talvez seja a interioridade dialética e justa que se ocultasse no seio das aparências, aquilo que se comunique em éteres, e não em matéria corpórea (ao corpo que o sente); talvez, a bruma que pesa na alma mas não se abstrai pelo espírito, - esse "informe real" só se poderia vir a conhecer quando em sono, em que dormisse, e em que, dormindo, assim se lhe mostrassem as formas sem forma, que habitam a noite; e, assim, ele dormisse, desperto na realidade imaterial. Dormisse e se acordasse, divergindo sombra e luz, se perdendo da luz com a noite, adensando com a noite o luzir, em constante batalha entre as imparidades que, misteriosamente, convergem contrárias. E, nesse ínterim, de entre realidades, apressando-se, da bruma para a bruma; concluindo-se, então, em coisa nenhuma. E lhe seria, portanto, impossível a obtenção de qualquer realidade, tão só a "externa sonolência" do mundo aparente em suas formas sonhadas, em ouro e cinza. E sua alma estava eternamente perdida. E ele se afogara para dentro.

Mas, se o Pessoa ele mesmo submergira-se da névoa, se emaranhara à possibilidade do eu uma procissão de sombras esvoaçadas que the vinham e esvaíam-se sem conclusão alguma; se assim o mundo a que pertencia era um exílio de formas aparentes encobertadas pela interioridade metafísica do Ser, fazia-se necessário então que da dispersão crônica de si se alenvantasse enfim a voz do Eu. Essa voz emergira, mas não fora assim erguida da plenitude unitária de uma identidade conclusa em si mesmo, mas da plenitude unificante de um Ser Absoluto que fazia a quantidade (ou a multiplicidade) a própria identidade do Uno.

O Pessoa ele mesmo evocara o Mar-sem-fim das divagações etéreas, das formas sem corpo, e a amplitude marítima de sua alma fazia o Ser um pensamento sonhado sem tempo ou 
espaço. O veio épico de seu pensamento manifestara a presença do eterno entre as composições fenomênicas do cosmos. O meio fenomênico fizera-se então carregado em tal profundidade do intelecto pensado das formas e das emanações invisíveis da essência que a própria realidade concebida desfizera-se. A realidade devia ser então reassumida pelo poeta.

Álvaro de Campos, também como o Pessoa ele mesmo, evocara o Mar na dinâmica de seus versos, mas esse Mar não traria agora o sentido esfumaçado e perdido de seu par heteronímico, nem traria promessas de feitos e heróis ou a patética clássica do mundo mítico. Dava-se agora o Cais Absoluto, junto da dissolução do efêmero no tempo.

Sim, dum cais, dum cais dalgum modo material,

Real, visível como cais, cais realmente,

O Cais Absoluto por cujo modelo inconscientemente imitado,

Insensivelmente evocado,

Nós os homens construímos

Os nossos cais de pedra atual sobre água verdadeira,

Que depois de construídos se anunciam de repente

Coisas-Reais, Espíritos-Coisas, Entidades em Pedra-Almas,

A certos momentos nossos de sentimento-raiz

Quando no mundo-exterior como que se abre uma porta

E, sem que nada se altere,

Tudo se revela diverso.

(PESSOA, 1997, p. 316).

Dessa maneira, evocando o Cais Absoluto, ele evocará a essência unitária e dará às coisas do mundo corpóreo uma procedência comum, um ponto de partida e, talvez, de retorno. As coisas todas, em seu princípio potencial, não partirão senão desse mesmo Cais único, que lhes tributa a unidade a todas; e, assim, proliferar-se-ão em corpo aparente, segundo um princípio científico que as regerá em substância, — vindo a ser cada coisa em seu modo, na vida do cosmos material. Mas Campos não quer abranger uma essência platônica transcendente quando clama o Cais, ele está ocupado da realidade imediata e, por isso, ele diz de um Cais Absoluto que seja material, real, visível... Campos cavará nos seus versos a substância imediata do mundo: A essência procederá tão só do que aparente no mundo físico em sua realidade direta, fenomenologicamente, em voga de que a aparência exponha a essência e a essência, assim exposta, se faça ela própria no tempo justo em que se mostre no aparente; e o devir farse-ia, pois, existencialista, na proposição de que a cada instante o pensar que se amolde 
emoldure o presente substancial do ser que o pense. Melhor que nos coloquemos a par deste pensamento de forma mais clara...

O Penso, logo existo cartesiano vigora em Campos tanto no aparentar fenomênico como no psiquismo mnemônico. Se eu penso, e se eu sou o que penso, e no momento em que entro em contato com meu pensamento eu existo, sendo eu meu pensamento, diverso do que eu fora antes de pensá-lo, procede que a minha essência amolda-se no instante exato em que contemplo o pensamento que se me faz na mente, ou na alma. Portanto, a minha essência virá a fazer-se a partir do meu devir momentâneo e eu não terei existência substancial para antes de amoldar-se a presença presente do meu acontecer. A minha existência será pois minha própria essência e o pensamento da minha essência será pois minha própria presença. Como se a essência aprendesse agora a sua forma eterna, não na perfeição do princípio imóvel, mas no instante transformacional de seu corpo aparente. Com isso, o devir fenomênico das coisas também se amoldará substancial. O intelecto da forma aparente faz manifestar-se em presença a essência do objeto (a lei que o determina) no limiar do acontecer momentâneo de sua existência. E o pensamento então se pensa — neste instante, não anterior a este instante — a partir do devir virtual de que sucede a realidade. Dessa maneira, a forma eterna de uma representação corpórea, eterna porque seja substancial em si mesma, não será ela senão o justo pensamento imediato do conteúdo de uma expressão física, de tal forma pensado que aparente então o seu presente instantâneo. Com isso, a espontaneidade do devir momentâneo das formas representará a forma platônica, mas ao reverso e às antenas que a captam instantaneamente (no caso dos homens, seus sentidos), e o tempo presente da matéria assegurará, assim, o eterno presente da essência.

Dessa forma, se do aparente efêmero momentâneo faz-se a própria essência objetiva das formas, poder-se-ão dar assim as "Coisas-Reais" de que falara, os "Espíritos-Coisas", as "Entidades em Pedra-Almas", que partindo do Cais seguem para a fecundidade transformacional do constante devenir da matéria e de sua constante inconstância existencial. E sem que nada se altere, porque tudo o que partiu do Cais leva a memória constitutiva dele consigo, pois então se revela o diverso, a partir da lei que o rege; e só se revela porque já existia nas adegas do tempo guardado, senão se faria assombração do nada. E como, nesses veios, tudo parta do Cais, de passagem no tempo, rumo a terras distantes, num avanço irrequieto, tão só com a vontade de fazer-se e de ser e vir a ser, pois então se fará aludir em Campos o tempo das máquinas, a brevidade intolerante do autoconsumo, a eterna efemeridade tecnológica do Ser. 
Maravilhosa vida marítima moderna,

Toda limpeza, máquinas e saúde!

Tudo tão bem arranjado, tão espontaneamente ajustado,

Todas as peças das máquinas, todos os navios pelos mares,

Todos os elementos da atividade comercial de exportação e importação

Tão maravilhosamente combinando-se

Que corre tudo como se fosse por leis naturais,

Nenhuma coisa esbarrando com outra!

(PESSOA, 1997, p. 332).

É-se assim o tempo do consumismo exacerbado, mas não por princípio capitalista da sociedade "civilizada" tão somente, é-se o tempo da própria essência natural das coisas fazerse ao molde do progresso e da política interna que o seduz: "Grandes hotéis do Infinito, oh transatlânticos meus! / Com o cosmopolitismo perfeito e total de nunca pararem num ponto / E conterem todas as espécies de trajes, de caras, de raças!” (PESSOA, 1997, p. 334).

Em análise do conceito de modernidade avidamente discutido em Walter Benjamin mediante suas leituras de Baudelaire, Bernd Witte circunscreve em artigo a sociedade suicida que velara o filósofo, nova sociedade emergente, que ao tempo da oferta do novo - diante dos moldes de consumo modernos - faz (ao novo) internamente o seu perecimento, como se o produto ofertado pela modernidade trouxesse em si, na disposição da oferta, o esvaziamento monótono e entediado de sua existência útil. Útil até a gastura e o cansaço implícitos no modo de produção e consumo burgueses, que prezariam sim o produto descartável. Inútil então, pois que, ao tempo que seja entregue ao mundo capitalista da oferta, é-lhe deferida a substituição através de um mercado que altera valores tão-logo se deem. Em decorrência disso, a "efetividade e durabilidade são impossibilitadas pelo princípio da modernidade. Pois o que acaba de ser criado é imediatamente algo envelhecido e é vítima do desprezo e do esquecimento" (WITTE, 1992, p. 106).

Nos tempos antigos, poderia ser dito, o fenecer das coisas e, com ele, a possibilidade de empregá-las como signos em contextos alegóricos, era produzido mediante processos lentos, como que naturais, ou por catástrofes da natureza. A antiguidade torna-se antiguidade de duas formas: seja por morrer aos poucos, seja por ser enterrada por uma catástrofe natural, e o exemplo mais conhecido disso é naturalmente o de Pompéia e Herculano, soterrados por um monte de cinzas.

O que, ao meu entender, Benjamin pretende dizer é que a modernidade se caracteriza pelo fato de não mais deixar o envelhecimento e a morte aos cuidados dos processos naturais, mas de colaborar no seu planejamento e encenação. Este é o processo básico que se impôs durante a industrialização e que também foi transferido para o campo da cultura: as coisas não têm tempo de envelhecer. (...) As coisas não têm mais tempo suficiente para 
envelhecer, mas são produzidas de tal modo que são velhas desde o início e devem ser substituídas por coisas novas. (...)

O envelhecimento, se quisermos guardar esta palavra, deve ser entendido como a morte das coisas e dos valores culturais, coproduzida desde o início. (...) A diferença fundamental é a seguinte: a antiguidade histórica transformou-se em tal devido a processos ou catástrofes naturais; na modernidade o processo de perecimento está incluído no processo de produção, ou seja, na forma da produção material. (WITTE, 1992, p. 106 107).

Com essa citação, queríamos não alegar uma crítica ao templário burguês na poesia de Campos, nunca, pois em nenhum momento ele se mostrará diretamente politizado pela intenção crítica do capital e do mercado. Queremos, de outra mão, alegar sim que o veio existencialista do poeta aderiu à realidade do consumo moderno a própria essência cosmológica da vida, partindo assim do Cais Absoluto de que "nós os homens construímos / Os nossos cais de pedra atual sobre água verdadeira" (PESSOA, 1997, p. 316). Ora, a máquina é, pois, a própria consequência progressiva da essência primeira não só do homem, mas de todo um cosmos em constante movimento: "Em vós, ó coisas grandes, banais, úteis, inúteis, / Ó coisas todas modernas, / Ó minhas contemporâneas, forma atual e próxima / Do sistema imediato do Universo! / Nova Revelação metálica e dinâmica de Deus!” (PESSOA, 1997, p. 308).

Como a antiguidade viera a ser soterrada nas cinzas dos processos naturais, Campos dános a entender que também a sociedade de consumo amonta-se no seio desses processos. A realidade ela própria consome-se com a dinamicidade da oferta do capital. Portanto, a Natureza angaria em si o consumismo inato de seu próprio corpo no egotismo intrínseco de sua ânsia por eternamente vir a ser, se fazer. Dessa mão, o progresso e o futurismo em Campos podem figurar o próprio devir virtual do ser contíguo das coisas, a própria potencialidade ativa daquele fogo de que fizera Heráclito de Éfeso o vórtice incessante do todo.

\author{
Eia! eia! eia! \\ Eia eletricidade, nervos doentes da Matéria! \\ Eia telegrafia-sem-fios, simpatia metálica do Inconsciente! \\ Eia túneis, eia canais, Panamá, Kiel, Suez! \\ Eia todo o passado dentro do presente! \\ Eia todo o futuro já dentro de nós! eia! \\ Eia! eia! eia! \\ Frutos de ferro e útil da árvore-fábrica cosmopolita! \\ Eia! eia! eia, eia-hô-ô-ô! \\ Nem sei que existo para dentro. Giro, rodeio, engenho-me. \\ Engatam-me em todos os comboios. \\ Içam-me em todos os cais. \\ Giro dentro das hélices de todos os navios. \\ Eia! eia-hô eia! \\ Eia! sou o calor mecânico e a eletricidade!
}


(PESSOA, 1997, p. 311).

De maneira que a "simpatia metálica do Inconsciente" é evocada, evocando a organização de uma Mente movida mais pela paixão acidental do acontecer inconsciente que pela consciência administrativa de uma ciência exata (a não ser em viés de uma ciência implícita de todo processo), faz-se assim unir na evocação a inconsciência cosmogônica dos "nervos doentes da Matéria" à progressão inesgotável do devir futurista. Dessa forma, diante da contiguidade histórica ininterrupta, só pode haver ao fim, como o fora no princípio pela consubstanciação dos elementos, o caos absoluto. Mas o caos civilizacional do ferro e do aço.

\footnotetext{
Ó ferro, ó aço, ó alumínio, ó chapas de ferro ondulado!

Ó cais, ó portos, ó comboios, ó guindastes, ó rebocadores!

Eh-lá grandes desastres de comboios!

Eh-lá desabamentos de galerias de minas!

Eh-lá naufrágios deliciosos dos grandes transatlânticos!

Eh-lá-hô revoluções aqui, ali, acolá,

Alterações de constituições, guerras, tratados, invasões,

Ruído, injustiças, violências, e talvez para breve o fim,

A grande invasão dos bárbaros amarelos pela Europa,

E outro Sol no novo Horizonte!

(PESSOA, 1997, p. 310).
}

Em visão desse caos transformacional implícito na essência do Mundo, Campos tornase também apocalíptico e anuncia "outro Sol no novo Horizonte", um fim talvez para breve, se em sua postura futurista ele não pode ver senão um progresso incontrolável da Matéria e do construto. Ora, o que tão só progride é como uma bolha que inchasse, como a existência que inchasse em pulmões tecnológicos, e se o enchimento, com o ar que assoprasse incansável da essência, se ele é irreprimível, resta-lhe estourar-se ou consumir-se de uma maneira ou de outra. E, sob esse viés, poderíamos entender, se fôssemos ousados em afirmar certas coisas, um processo de autoaniquilamento cósmico, como na disciplina de Física, da mesma forma que se inscreve o envelhecimento na modernidade benjaminiana de Witte. No entanto, como o Ser não pode se aniquilar a si próprio, promovendo assim sua autoextinção no vazio, pois então suas partes cuidarão de aniquilarem-se em resposta, devenindo, construindo, nascendo e morrendo, e assim mudando o imutável, e por isso aniquilando-o em seu princípio imóvel, forma que o próprio princípio imóvel do Ser movimentasse-se e, por isso, vivesse a morte no movimento de deslocação que ele próprio efetuaria sobre suas partículas. Portanto, o que se cria, dentro em si a si próprio se aniquila. Mas o que se cria se cria a partir da contiguidade e consubstanciação. Mesmo que o produto férreo nas mãos do artesão. Como nos fala Hannah 
Arendt em "A vida do espírito", quando consultando as prerrogativas da vontade em Aristóteles:

O produto humano, esse "composto de matéria e forma" - por exemplo, uma casa de madeira feita segundo uma forma pré-existente no espírito (nous) do artesão - , claramente não foi feito do nada; e, assim, Aristóteles compreendia que ele pré-existia "potencialmente" antes de ser atualizado por mãos humanas. Essa noção foi derivada do modo de ser particular da natureza, das coisas vivas, em que tudo o que aparece cresce de alguma coisa que contém potencialmente o produto final, como o carvalho existe potencialmente na semente e o animal no sêmen.

A visão de que tudo o que é real deve ser precedido de uma potencialidade como uma de suas causas nega implicitamente o futuro como um tempo verbal autêntico: o futuro nada mais é que uma consequência do passado, e a diferença entre as coisas naturais e as feitas pelos homens reside simplesmente na distinção entre aquelas cujas potencialidades necessariamente transformam-se em atualidades e aquelas que podem ou não se atualizar. (ARENDT, 1991, 198).

Portanto, tudo isso que há não procedera ao repente da civilidade moderna, mesmo que lhe fosse intrínseca a ela no veio do tempo; mas tudo isso viria preparando-se entre as eras, desde a história passada vinha se amontando, como fosse a própria potência evolutiva da existência, mas não só como construto copioso e atualizado da natureza do mundo, e sim como fosse em si a própria evolução do natural na resolução dos tempos:

Em febre e olhando os motores como a uma Natureza tropical -

Grandes trópicos humanos de ferro e fogo e força -

Canto, e canto o presente, e também o passado e o futuro,

Porque o presente é todo o passado e todo o futuro

E há Platão e Virgílio dentro das máquinas e das luzes elétricas

Só porque houve outrora e foram humanos Virgílio e Platão,

E pedaços do Alexandre Magno do século talvez cinqüenta,

Átomos que hão de ir ter febre para o cérebro do Ésquilo do século cem,

Andam por estas correias de transmissão e por estes êmbolos e por estes

Rugindo, rangendo, ciciando, estrugindo, ferreando, [volantes,

Fazendo-me um excesso de carícias ao corpo numa só carícia à alma.

(PESSOA, 1997, p. 306).

Campos verá, então, o devir tecnológico, como o próprio devir científico, não como uma ofensa raivosa da humana civilização aos desígnios dos deuses ou mesmo ao proceder natural do mundo. A Natureza ela própria trabalharia a inteligência humana para o erguer das selvas pétreas da civilização moderna, a própria Natureza, em seu princípio, evocara a máquina para que se revelasse enfim a estrutura metálica do Universo. E toda a antiguidade, toda ela, suicida, consumir-se-ia a si própria, cada tempo em seu tempo, autoaniquilando o corpo 
presente para consumar-se no futuro vindouro, no progresso, na resolução última da Natureza. Quando natureza e civilização - enquanto estrutura citadina pautada num progresso tecnológico e científico movido pela criação e organização humana - em Campos não diferem como ímpares, tal qual é a crença saudosista dos prados e regatos; um e outro são sim um mesmo Ser. Portanto, o passado se autoextinguiria; contudo: dispersando suas cinzas sob a profecia do progresso. E em dispersar-se-lhe as cinzas, via que esteja "todo o passado dentro do presente e todo o futuro já dentro de nós”, então, como o Pessoa ele mesmo, Campos, muito embora afirmara a realidade imediata do mundo, agora encontra a dispersão mnêmica do ser. A dispersão evolutiva da história. E perde-se o eu. Porque as cinzas do tempo assopram com o vento num movimento incessante de autoconhecimento e autoaniquilação. Como a brevidade do ser desmontasse o eu em partículas diante do devir mnemônico temporal, já que a essência se pensa neste exato momento, e o que se passara mnemonicamente perdeu-se como um alguém que o passado vivera e que se exista no presente tão só no desmembramento e inconstância de si.

Num repente, então, Campos entrechoca a sua realidade com a de seu heterônimo ortônimo e se afoga submerso como às névoas metafísicas do Pessoa ele mesmo.

\footnotetext{
Toma-me pouco a pouco o delírio das coisas marítimas,

Penetram-me fisicamente o cais e a sua atmosfera,

O marulho do Tejo galga-me por cima dos sentidos,

E começo a sonhar, começo a envolver-me do sonho das águas,

Começam a pegar bem as correias-de-transmissão na minh'alma

$\mathrm{E}$ a aceleração do volante sacode-me nitidamente.

Chamam por mim as águas,

Chamam por mim os mares,

Chamam por mim, levantando uma voz corpórea, os longes,

As épocas marítimas todas sentidas no passado, a chamar.

(PESSOA, 1997, p. 319).
}

Assim, Campos fará o retorno às ânsias marítimas. As águas lhe chamam, mas como dele mesmo a voz emergisse, como um delírio metafísico que se lhe fizesse, e o desejo de as navegar (as águas) e ultrapassar a ultrarrealidade do consumo e do envelhecimento faz-lhe o ser ansiar pelos longes, pelo indefinido. A evocação dos mares e das épocas marítimas faz-lhe almejar a Distância indissolúvel perante o Cais Absoluto e o ser de seus anseios e isso lhe fará também impotente diante do indecifrável, já que houvera visto a realidade corpórea absoluta, mas se pusera mesmo assim na mansidão do Ser.

A voz que se alevanta, o murmúrio das águas, o espírito dos mares, clamores do Cais, 
"Esse grito tremendo que parece soar / De dentro duma caverna cuja abóbada é o céu / E parece narrar todas as sinistras coisas / Que podem acontecer no Longe, no Mar, pela Noite..." (PESSOA, 1997, p. 320), essa voz de si, que o faz tencionar-se aos veios de sua essência, à compreensão turva e esotérica do Ser, essa voz lhe acordará cerrações e trevas, bússolas quebradas para a Noite. E ele poderia então compreender, envolto de angústia, a alegoria platônica da caverna, mas cuja abóbada, agora, era o céu, e, portanto, cujo sol fora inútil. Inútil em iluminar-lhe as sombras, projeções diretas mas pardas do externo objetivo. E sua alma, acorrentada, ansiara encontrar-se no informe em que se deitara, em que agora se aproximasse Campos de certa maneira do "informe real" que aturdira o Pessoa ele mesmo; em que agora, pois, sua alma perdera-se de si.

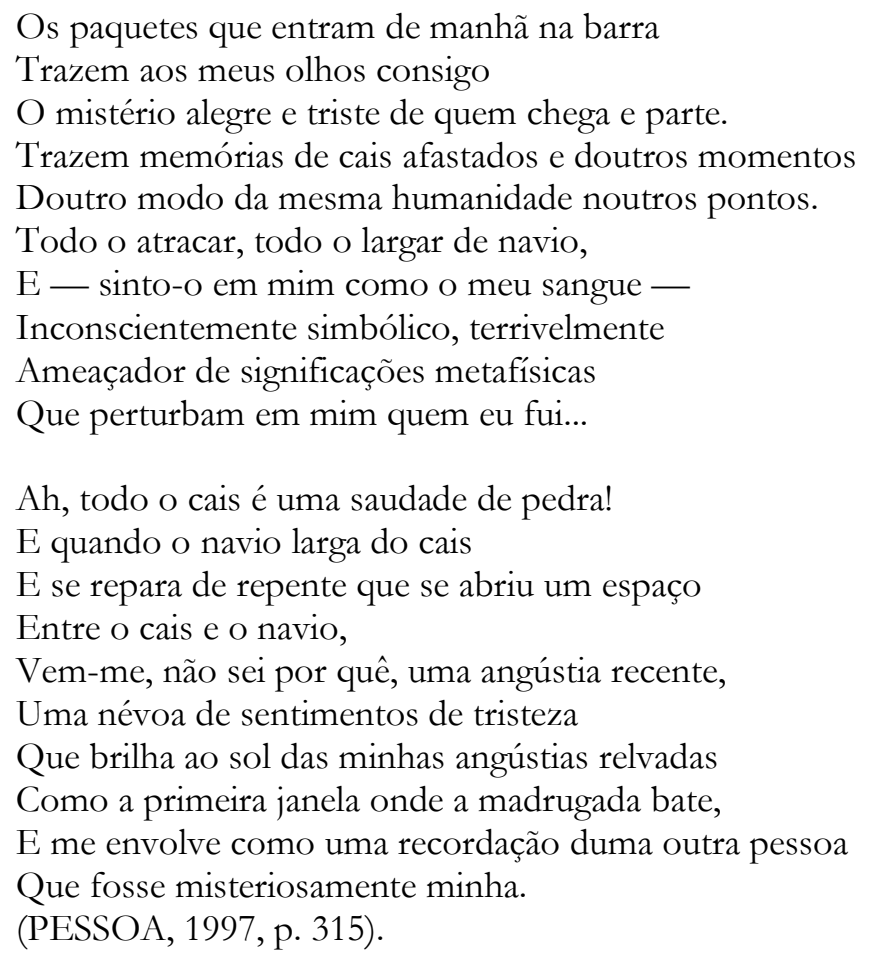

Mas ele evocara o Cais material, desde o princípio, por isso sua dispersão não se fazia essencialista como a do Pessoa, sua dispersão era existencial, era física e sensória: "Penetramme fisicamente o cais e a sua atmosfera" (PESSOA, 1997, p. 319), e todo o devir de sua consciência banida, "todo o atracar, todo o largar de navio" (PESSOA, 1997, p. 315), sentira ele nele como o seu sangue, não como em éteres, e sim como em álcoois e lapsos. Lapsos que se inscreviam perante as distâncias entre cais e navio, entre o que se passara, em que se fosse um dia aquilo, e o que viria a ser no acontecer diário da existência e de seu pensamento pensado. A efemeridade do tempo e o constante devir de cada coisa marcara a inutilidade da essência e do Ser diante da existência imediata, e o informe que aturdia a Campos far-se-ia assim a partir 
do desmonte caótico da realidade e de sua inconstância, que impedisse o conhecimento verdadeiro das coisas. A realidade, pois, novamente se mostraria como que colhida em versos do Pessoa ele mesmo, que também concebia a ilusão do presente em seu pensamento misticista: "Tudo tão inútil! / Tão como que doente / Tão divinamente / Fútil — ah, tão fútil / Sonho que se sente / De si próprio ausente...” (PESSOA, 1997, p. 107).

Assim, a realidade imediata das coisas, não poderia ser ela agora senão algo sonhado e falso, como que subjetivo, como que se o sentisse a esse algo que era ela e se o conhecesse também, só que em sua forma falsificada pela alma pensante que abstraísse ou que, devaneada, tão somente o sonhasse. Dessa maneira, essa realidade se faria ela mesma ausente de si, já que conluiava a brevidade temporal e a alma objetiva do que se mostra, já que, de tal modo, se perdia na lógica do tempo a circunstancialidade perceptiva do ser: "E só punge ver, / Ao longe, iludida, / A vida a morrer / O sonho da vida." (PESSOA, 1997, p. 143).

Dessa forma, não só a realidade corpórea se autoaniquila nas distâncias, nem só ela se perde na Noite indecifrável do eterno devenir, mas a própria consciência devaneada se extingue na realização do presente chegado. O sonho da vida, o que devaneamos em nossos processos mnêmicos, morre a partir do devir intelectual, como a vida morre a partir da temporalidade do efêmero. Tão só resta a vida iludida, a ilusão que nos alega a falsa realidade. Tão só resta a instabilidade do Ser e, por isso, a incompreensibilidade inata do que Ele seja:

Ah, as praias longínquas, os cais vistos de longe,

E depois as praias próximas, os cais vistos de perto,

O mistério de cada ida e de cada chegada,

A dolorosa instabilidade e incompreensibilidade

Deste impossível universo

A cada hora marítima mais na própria pele sentido!

(PESSOA, 1997, p. 317).

E se se faz impossível o Universo. E, se a unidade parece inalcançável, só poderia restarlhe que a dispersão do ser se conclamasse enfim dos fossos da alma.

A minha alma partiu-se como um vaso vazio.

Caiu pela escada excessivamente abaixo.

Caiu das mãos da criada descuidada.

Caiu, fez-se em mais pedaços do que havia loiça no vaso.

Asneira? Impossível? Sei lá!

Tenho mais sensações do que tinha quando me sentia eu.

Sou um espalhamento de cacos sobre um capacho por sacudir. 
$[\ldots]$

$\mathrm{O}$ que era eu um vaso vazio?

Olham os cacos absurdamente conscientes,

Mas conscientes de si mesmos, não conscientes deles.

(PESSOA, 1997, p. 378).

Mas se Campos se dissera um vaso vazio, é incompreensível pensar que desse vazio que ele fora far-se-ia em si o múltiplo que havia de ser, a um tempo só nada e vários, quando se lhe quebrasse a loiça e se dispersassem os cacos em vários de si mesmo, mais do que fora ele antes, um vaso vazio. Para explicar tais dizeres, clamamos à voz do crítico Massaud Moisés, este que em breve exposição - em "A Literatura Portuguesa" - abrange enigmas fundos da obra de Fernando Pessoa, com um modo de dizê-lo oportunamente filosófico e cientificamente desvendador:

\begin{abstract}
Mergulhado abissalmente no plano das relatividades, e só compreendendo e sentindo as coisas e os sêres dentro dum inalterado relativismo, - o poeta anseia atingir, pela análise ordenadora da caótica relatividade em que vive, o plano dum qualquer absoluto, isto é, de qualquer verdade capaz de resistir à sua impressão de desintegração total, ou de superar a inconstância relativa de tudo.

Por outras palavras: descrendo, ao mesmo tempo pela análise e a priori, num imutável Absoluto em si, mas sentindo ser êle indispensável para explicar o caos cósmico e conferir-lhe a ordem perdida pela simples meditação racionalista, - o poeta parte do relativo (ou Relativo) para o absoluto (ou Absoluto). Tudo se passa como se Fernando Pessoa, fenomenològicamente colocado diante do mundo, tentasse reconstruí-lo ou ordená-lo, partindo do nada, da estaca zero, recebendo como se fôsse pela primeira vez os impactos mil vêzes recebidos pelos homens no curso da História e sentindo-os como descoberta "pura", isenta de qualquer deformação intelectual anterior. (MOISÉS, 1973, p. 298).
\end{abstract}

A partir das palavras de Moisés, poderíamos pensar então que este vaso vazio que ele se diz ao princípio, antes que se lhe derrubasse a "loiça" e se lhe fizesse em pedaços, quando então fosse ele os próprios cacos de si mesmo; esse vazio de si seria justamente a partida que efetuara para a episteme do mundo, desancorando da estaca zero e seguindo para o indecifrável de sua alma. Isso em vista de que o mundo, como existiam os homens, lhe era também a ele não mais que um vaso vazio. Dentro dele, o mundo, um vaso vazio, de crenças vazias, em que os conceitos, intumescidos de preconceito e discriminação, estipulados no vazio, lhe eram também eles, os conceitos, um vaso vazio, vazio de significação, vazio de sentido. Um vaso vazio. $\mathrm{O}$ mundo, como se cria no mundo, um vaso vazio, que não lhe dizia nada. E ele, imerso pelo mundo, um vaso vazio, sem serventia nenhuma. 
Como se lhe ausentasse então toda e qualquer noção de ser, de si e das coisas, do conceito ao preconceito, conforme o Pessoa ele mesmo:

\author{
Em meus momentos escuros, \\ Em que em mim não há ninguém, \\ E tudo é névoas e muros, \\ Quanto a vida dá ou tem, \\ Se, um instante, erguendo a fronte, \\ De onde em mim sou aterrado, \\ Vejo o longínquo horizonte \\ Cheio de sol posto ou nado... \\ (PESSOA, 1997, p. 177).
}

Se lhe ausentasse então toda noção epistemológica preconcebida na história para que, assim, a partir do vazio, livre dos preceitos que o mundo lhe estipulara, — dentro em uma primitividade nevoenta que lhe vazasse o descobrimento das coisas, à Nietzsche, embatendose contra o muro socioestrutural que lhe quisesse cessar a possibilidade de avançar deste ponto para o conhecimento de si e do mundo, muito embora aterrado do em si que lhe fosse tão só caos, relatividade e nó - ; para que, desse ponto, do princípio e do nada, começasse a colher, cambo como a um doente fadado pela esquizofrenia temporal, desde o nada, colher estilhaços históricos a partir de si mesmo — "Quanto a vida dá ou tem" - em face de que organizasse no mínimo uma possibilidade filosófica unitária que o levasse a crer, para além do vazio, numa realidade corpórea ou mesmo metafísica, mas concreta perante o Mundo ou o cosmos.

Êsse processo fenomenológico pressupõe, necessàriamente, a multiplicação ilimitada do poeta em quantas criaturas compuseram e compõem a Humanidade na sequência dos séculos; pois apenas dêsse modo, isto é, somando as várias visões e verdades relativas de tôda a espécie humana no tempo e no espaço, e de cada homem ao longo de sua vida particular, seria possível ter uma imagem aproximada do Universo como um todo, e tentar reconquistá-la ao caos das relatividades. O fulcro, portanto, da cosmovisão pessoana é constituído por um esfôrço no sentido de conhecer o Universo, como um absoluto possível e para além da contingência individual. (MOISÉS, 1973, p. 298 - 299).

Então, o poeta havia de chamar as eras para dentro do presente, para dentro de seu tempo evocar o Mar Absoluto, para que diante do passado compreendesse a atualidade do progresso e para que amoldasse, na visão progressiva do tempo, o tempo presente do Ser, e para que, envolto da síntese dialética da História, pudesse então projetar o futuro e abarcar, assim, a totalidade, a unidade, o todo, sem mais tempo ou espaço. 
Homens do mar atual! homens do mar passado!

Comissários de bordo! escravos das galés! combatentes de Lepanto!

Piratas do tempo de Roma! Navegadores da Grécia!

Fenícios! Cartaginenses! Portugueses atirados de Sagres

Para a aventura indefinida, para o Mar Absoluto, para realizar o Impossível! (PESSOA, 1997, p. 321).

Dessa mão, em contradizer-se o ser ininterruptamente é que se lhe amonta uma possibilidade de atingir a "verdade" e se lhe faz, portanto, a contradição o único método organizacional que o pudesse levar ao caminho da Totalidade. A realidade dinâmica de Campos, que se contradiz em cada manifestação fenomênica de devir das coisas, ela faz-se a realidade existencial íntima do poeta dos heterônimos, ela molda a dialética ininterrupta da perscruta de si e da intimidade das coisas: "Sentir tudo de todas as maneiras, / Ter todas as opiniões, / Ser sincero contradizendo-se a cada minuto, / Desagradar a si próprio pela plena liberdade de espírito, / E amar as coisas como Deus.” (PESSOA, 1997, p. 347).

Só insurgindo da estaca zero do conhecimento, renegando todos os valores dados ou impostos, _ “Renego. / Renego tudo. / Renego mais do que tudo.” (PESSOA, 1997, p. 380) —, sentindo uma vez mais, contudo por si próprio, o que a humanidade sentira desde o princípio da história, contradizendo-se e desagradando-se em visão dos problemas quer morais, quer quaisquer que se interponham à episteme de si e do mundo em vigor, renegando-se a si próprio e à estruturação educacional de sua existência intelectual, só assim teria a liberdade de espírito para tomar conhecimento do mundo físico e espiritual de si mesmo e de ao redor. E só com a plena liberdade de espírito poderia julgar o conhecimento da Natureza em seu princípio, sem conceituá-la a partir do preconceito do mundo. E daí Massaud Moisés nos dirá:

Em consequência, Fernando Pessoa acaba por negar tôda verdade unitária, isto é, que não implique em contradição, e as demais — sempre paradoxais ou antitéticas —, êle as desmonta com paciência de relojoeiro, peça a peça, em busca duma essência que só existe, precisamente, na dualidade ou ambiguidade revelada e fragmentada: o relógio faz-se em dezenas de peças, pois que o relógio só existe no congraçamento harmônico de tôdas elas, e jamais de cada uma em particular ou do mero ajuntamento caótico, como ocorre depois do desmonte silencioso, paciente e alquímico, em busca do nada (que é tudo). (MOISÉS, 1973, p. 302).

Portanto, se nos torna claro o que dizia Campos sobre a "loiça" do vaso que ele era, que se quebrara disperso com o descuido da criada, em quando olhassem "os cacos absurdamente conscientes, mas conscientes de si mesmos, não conscientes deles". Ora, qual o relógio que o relojoeiro desmonta cada peça em busca do funcionamento preciso da totalidade, cada peça contendo a precisão metálica do engenho potencializador do agrupamento, os cacos 


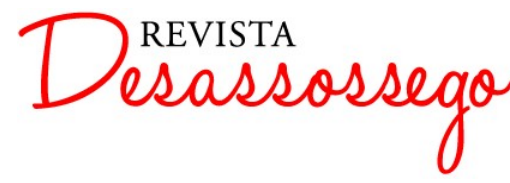

DESASSOSSEGO 20 - parte 2 | JUN/2019 | ISSN 2175-3180

DOI: http://dx.doi.org/10.11606/issn.2175-3180.v11i20p301-321

de Campos se conscientizam eles de si mesmos e passam a pensarem-se em sua existência diversos da unidade que os conceberia, sem a consciência de serem cacos, mas com a concessão de se pensarem eles próprios unidades de si. Cada pedaço partido olharia com a perspectiva singular de seu pensamento para o mundo e para as coisas, cada um compreendendo-se a si próprio. Pois, então, haveria de necessitar-se tão só uma consciência que os agrupasse a eles e deles, como o relojoeiro, extraísse o funcionamento totalizador das partes, o fundo de alma que guiaria os passos avulsos das peças. Mas se se houvera quebrado o vaso, e se se houvera mais do que ele próprio disperso no capacho a sacudir, então a possibilidade do funcionamento unitário das partes não passara de uma possibilidade, em que ele ficasse eternamente no possível de si, e a possibilidade da afirmação do Eu, como as partes se pensassem a si próprias, fizerase assim só um propósito, que se extinguira ao pé do múltiplo. Nesse viés, ele lamentaria a impossibilidade de ser: "Sou quem falhei ser. / Somos todos quem nos supusemos. / A nossa realidade é o que não conseguimos nunca.” (PESSOA, 1997, p. 388). E a sua realidade verdadeira fizera-se eterno ínterim ou vácuo substancial: "Se ao menos endoidecesse deveras! / Mas não: é este estar entre, / Este quase,/ Este poder ser que.../ Isto.” (PESSOA, 1997, p. 390).

Ele era, assim, não mais que o espaço vago que habitasse dentro de si e que nunca poder-se-ia ser deveras, porque ele próprio era só uma tentativa, era uma esperança vaga de devir, uma confissão anônima de outrem, um alguém que nunca existira, mas que tão só quase, que tão só isto. Punha-se pois, em vista do Pessoa ele mesmo, a habitar sua própria ausência: "Não tenho sentido, / Alma ou intenção... / 'Stou no meu olvido... / Dorme, coração...” (PESSOA, 1997, p. 129).

Mas há uma diferença aqui: se o Pessoa ele mesmo dormira no olvido de si, se se dissolvera nos nós metafísicos de sua alma atlântica e mítica, em Campos a sua dispersão se dera historicamente, se dera corporeamente no corpo da História. Como o dizia: "Sentir tudo de todas as maneiras" (PESSOA, 1997, p. 347). Deveras, para o conhecimento humano e animal, — segundo o entendimento mais recente, como a fenomenologia —, o que se conhece se conhece através dos sentidos do corpo, à guisa de processá-los mediante sensações e pesálos de forma ou outra ou simplesmente receptá-los pelo espírito. Então, sua dispersão, a de Campos, era ela epistêmica, mnêmica, temporal, não o emaranhado turvo de sombras que levara seu parente heteronímico à vestimenta metafísica melancólica da realidade. Diante disso, a efemeridade de Campos, fora ela tão-somente corpórea, porque se dera mediante os sentidos do corpo e os sentidos do corpo obedecem, claramente, à circunstancialidade momentânea das formas aparentes. E as circunstâncias sentidas, é-o sabido, tão logo se sintam, amanhã se 
dissipam, restando-lhes tão só a memória guardada e talvez a sensação dolorosa, - como o dizia na "Ode triunfal”: "À dolorosa luz das grandes lâmpadas elétricas da fábrica / Tenho febre e escrevo" (PESSOA, 1997, p. 306) —; a sensação dolorosa do sofrimento que albergasse a alma diante da eterna impossibilidade de alcançar-se uma outra vez o que se passou. No entanto, ao menos a realidade que concebera não se lhe dispersara ou desfizera, a sensação acordava com ele real e lhe era possível afirmá-la, e lhe era possível, pois, a sinceridade perante a physis e a existência, para que Fernando Pessoa, talvez, através dele se afirmasse como um alguém:

[...] se se pusesse o falacioso problema da sinceridade, dir-se-ia que através de Álvaro de Campos o poeta se revelaria "sincero" e despojado; Álvaro de Campos seria o "Fernando Pessoa" de quem Fernando Pessoa seria heterônimo, como se, na verdade, tivéssemos um poeta, Álvaro de Campos, e um seu heterônimo, Fernando Pessoa. (MOISÉS, 1973, p. 301).

Sob tal circunstância, Álvaro de Campos assume o peso de carregar o poeta Pessoa dos heterônimos em si, pondo a sinceridade da confissão apaixonada diante de seus versos, não lhe cabendo senão afirmar deveras um eu, um eu que de alguma forma pudesse ser afirmado, se não dele, nele. Suprindo, assim, a necessidade do ortônimo em existir, em se afirmar no mundo, não sendo apenas uma eterna sombra, um sim-não; livrando-o, talvez, de enlouquecer e de dissipar-se, obumbrado que estava seu inquieto espírito.

\section{Referências:}

ARENDT, Hannah. A Vida do Espírito. Rio de Janeiro, RJ: Relume Dumará, 1991.

CARNEIRO, Mario Sá. Todos os poemas. 2a ed. Rio de Janeiro: Nova Aguilar, 1976.

MOISÉS, Massaud. A Literatura Portuguesa. 11 ed. São Paulo: Cultrix, 1973.

PESSOA, Fernando. Obra poética. Rio de Janeiro, RJ: Nova Aguilar, 1997.

Pré-socráticos. São Paulo: Nova Cultural, 2005.

WITTE, Bernd. Por que o moderno envelhece tão rápido?: Concepsão da modernidade em Walter Benjamin. in: REVISTA USP (Dossiê Walter Benjamin). São Paulo, n. 15, 1992. 